ELORE (ISSN 1456-3010), vol. $18-1 / 2011$.

Julkaisija: Suomen Kansantietouden Tutkijain Seura ry.

[http://www.elore.fi/arkisto/1_11/kirjat_hytonen.pdf]

KIRJA-ARVIO

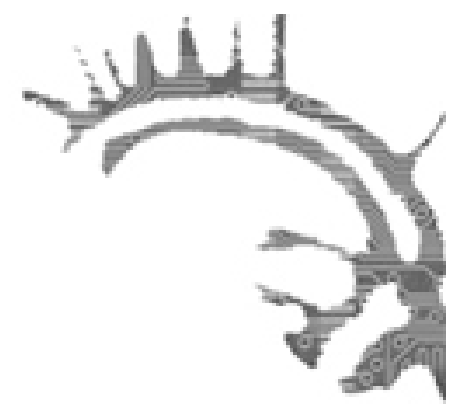

\title{
RETKIÄ USKONTOTIETEEN KENTILLE
}

ANTTONEN, VEIKKO 2010: Uskontotieteen maastot ja kartat. Tietolipas 232. Helsinki: SKS. 286 sivua.

\section{Elina Hytönen}

Veikko Anttosen kirjan Uskontotieteen maastot ja kartat tarkoituksena on tarjota perustason oppikirja niin uskontotieteen, kulttuurintutkimuksen kuin teologiankin opiskelijoille, mutta samalla avata uskontotieteen parissa käytäviä keskusteluja myös muille uskontotieteestä kiinnostuneille lukijoille. Kirja alkaakin johdannon nopeahkolla katsauksella siihen, mitä uskontotiede pitää sisällään ja miten sen eri alat - uskontoantropologia, -sosiologia, -psykologia, -historia ja -fenomenologia - eroavat tosistaan. Laajasti määriteltynä uskontotieteen tehtävänä on tutkia kaikkea inhimillistä ajattelua ja toimintaa, jonka eri kriteerien perusteella voidaan katsoa kuuluvan uskonto-käsitteen piiriiin. Tämä tarkastelu tehdään suhteessa ympäröivään yhteiskuntaan ja kulttuuriin.

\section{HiSTORIA, TEORIA JA KÄYTÄNTÖ USKONTOTIETEESSÄ}

Kirjan ensimmäinen luku käsittelee uskontotieteen kehitystä 1800-luvulta 1900-luvun puoliväliin saakka. Katsauksessa käydään lävitse uskontotieteen kansainvälistä kehitystä ja annetaan varsin hyvä lähtökohta uskontotieteen peruskäsitteiden ja teorioiden ymmärtämiseen menemättä liiallisiin yksityiskohtiin. Kansainvälisiä suuntauksia tarkasteltuaan Anttonen kääntää katseensa kohti suomalaisen uskontotieteen kehityskulkuja sekä täällä tieteenalaan vaikuttaneita tutkijoita ja teoreetikoita. Tarkastelu alkaa uskontotieteen esihistoriasta ja Agricolan runomitallisesta hämäläisten ja karjalaisten epäjumalien luettelosta.

Varsinaisen etnografisen tiedonintressin Anttonen katsoo alkaneen M. A. Castrénista (1813-1852). Siitä eteenpäin kansanuskoa käsittelevää tietoa ryhtyi tuottamaan tutkimusyhteisö, joka määritteli itse tutkimuskysymykset ja valintakriteerit. Castrén toi Suomeen myös tutkijan omakohtaisen kenttätyön. Otto Donner avasi uusia ovia 
suorittamansa myyttitutkimuksen kautta, kun Julius ja Kaarle Krohn puolestaan kehittelivät maantieteellis-historiallista metodia. Tarkastelu sisältää edellä mainittujen lisäksi Uno Harvan, Martti Haavion sekä Edvard Westermarckin koulukunnat. Tällaista historiallista tarkastelua Anttonen pitää tärkeänä siksi, että tieteentekijöiden täytyy pystyä selittämään sekä suurelle yleisölle että muulle tiedeyhteisölle, miksi uskontotieteen akateemiset perinteet ovat rakentuneet sellaisiksi kuin ne nykyään ovat. Tähän Anttonen tuntuukin ensimmäisen luvun tarkastelullaan pyrkivän.

Kirjan toinen luku tarkastelee muun muassa sitä, miten uskonto on syntynyt, minkälaista osaa se näyttelee eri kulttuureissa sekä miten kulttuurin ja uskonnon voidaan katsoa kietoutuneen toisiinsa. Uskonnon taustaa käsittelevän osion jälkeen Anttonen luo silmäyksen länsimaisen uskontokäsityksen juuriin aloittaen tarkastelun antiikin Roomasta ja religio-sanan monimerkityksisyydestä eri aikakausina. Anttonen osoittaa, miten erilaiset rajanvedot esimerkiksi uskonnon ja taikauskon tai uskonnon ja magian välillä ovat edelleen olennainen osa uskontotieteen keskusteluita. Uskontoa on varsin hankalaa kartoittaa kattavasti, sillä se on juurtunut syvälle yhteisöiden ajatteluun ja käyttäytymiseen. Mark C. Tayloria $(1991,1)$ lainaten Anttonen toteaakin, että uskontoa on pidettävä liukkaana käsitteenä, joka on usein mielenkiintoisin juuri siellä, missä se on vähiten odotettavissa.

\section{PyHÄN KÄSITE USKONTOTIETEESSÄ}

Kirjan kolmas osio alkaa keskustelulla siitä, miten uskonto sekä sen erilaiset säännöt ja kiellot elävät ihmisten käyttämässä kielessä ja miten ne suorastaan syntyvät siitä. Käytössä oleva kieli heijastaa osaltaan ympäröivää yhteiskuntaa, mutta samalla kieli myös muovaa sitä. Anttonen vertaa uskontoa kieleen todeten, että kielen tavoin uskonto on yhteisöllinen ilmiö, joka on nähtävissä sosiaalisen miljöön sisältämissä jaetuissa arvoissa ja normeissa. Tämän jälkeen Anttonen siirtyy käsittelemään pyhän käsitettä todeten sen olevan uskontotieteessä yksi perustavimmista mutta myös kiistellyimmistä käsitteistä. Tarkastelun keskiössä on se, miten pyhän käsitettä on käytetty Suomessa ja Virossa maa-alueita erottavien rajojen määritteenä mutta myös topografisesti jollakin lailla poikkeavien maastokohteiden merkitsijänä.

Anttonen toteaa pyhä-termin olleen näissä paikalliskulttuureissa erityisenä osana yhteisöelämän järjestyksen ylläpitämisessä jo esikristillisellä ajalla. Tämä selittää osaltaan sen, että kirkko ei ole kääntänyt latinan sacer-sanctus -sanaparia suomen kieleen, vaan on ottanut käyttöönsä alun perin maantieteellisen pyhä-termin muuttaen vain termin merkitystä. Nyky-yhteiskunnan tarkasteluun pyhä-termi antaa uudenlaisen tarttumispinnan, kun sen kautta katsotaan esimerkiksi kehonrakennusta tai plastiikkakirurgiaa. Anttonen toteaakin, että pyhä-termin semanttinen tarkastelu osoittaa uskonnon ja sosiokulttuurisen arvoerottelun olevan varsin lähellä toisiaan. Anttonen tarkastelee pyhä-termiä myös Victor Turnerin (Turner \& Turner 1978) käyttämien liminaalisuuden ja liminoidisunden käsitteiden kautta. Anttonen näkee liminaalisuuden yhteisöllisenä välitilana olevan yhtenevä pyhä-termin välittämien sosiaalisten merkitysten kanssa, sillä yksilöiden elämän aikana tapahtuvat erilaiset siirtymät kuten syntymä, avioliitto ja kuolema kuuluvat pyhän kategorian piiriin. Pyhä voidaankin nähdä eräänlaisena 
erottavana kynnyksenä.

Osan lopussa Anttonen käsittelee omaa pyhä-teoriaansa. Se esittää pyhän eräänlaisena kategoriarajana, joka nojaa kolmen ihmisen ajattelua ja käyttäytymistä ohjaavan tietorakenteen varaan. Näiden kolmen rakenteen - ruumiillisuus, yhteisöllisyys ja territoriaalisuus - sisäpuolisuuden ja ulkopuolisuuden sekä niitä yhdistävien ja erottavien rajojen tarkastelun kautta voidaan tarkastella, miten ihminen rakentaa kulttuuriaan ja uskontoaan. Teorian avulla voidaan Anttosen mukaan selvittää, miten sosiaalisia arvoja eli pyhäksi luokiteltuja asioita normitetaan ja suojellaan erilaisten kieltojen, määräysten ja sääntöjen kautta. Pyhän tarkasteleminen maaston ja kartan metaforien kautta auttaa tutkijaa ymmärtämään, ettei pyhä ole kohde, vaan suhde.

\section{SUOMI JA SUOMALAISUUS USKONTOTIETEEN SILMIN}

Kirjan neljäs osa tarkastelee pyhän käsitettä Suomen ja suomalaisuuden kautta. Luvun lähtökohtana on Émile Durkheimin ja Robert N. Bellahin näkemykset yhteiskunnasta uskonnonkaltaisena "pyhien asioiden" idealisoituna järjestelmänä. Kansanajattelua voidaan Anttosen mukaan tarkastella yhtenä uskonnollisen ajattelun muotona uskontotieteen tutkimusteoreettisten linjausten valossa. Pyhän määreet ovat nähtävissä myös esimerkiksi siinä, miten menneisyydestä kirjoitetaan ja miten itsenäisyyttä, vapautta ja alueellista koskemattomuutta vaalitaan kansallisina arvoina. Nationalismia voidaankin tarkastella heimouskontona. Tämä näkökulma lähtökohtanaan Anttonen lähtee tarkastelemaan kansakuntaa ja kansaa sen pyhyyden määreiden kautta. Fokukseen joutuvat muun muassa suomalaiset kristilliset ja mytologiset representaatiot sekä tilojen ja maisemien arvottaminen.

Tämän jälkeen Anttonen tarkastelee pyhä- ja hiisi-sanoja kielitieteen lähtökohdista toisiinsa kytkeytyvänä sanaparina. Anttonen palaa samalla tarkastelussaan ajatukseen, ettei pyhä ole ollut alkujaan uskonnollinen termi, vaan se on viitannut maastoon, aikoihin ja paikkoihin, joihin kytkeytyi käyttäytymistä säätelevä normi. Pyhän käsitteellä on ollut myös rajoja osoittava tehtävä. Anttonen käsittelee kirjassaan myös metsää ja eräluontoa myyttisenä kansallisessa kerronnassa esiintyvänä rajana. Metsän asettaman rajan ylittäminen on kansanuskossa usein ritualisoitu.

Metsän tarkastelun jälkeen Anttonen kääntää huomionsa jumaliin. Hän aloittaa tarkastelunsa jumala-sanan etymologisesta jäljittämisestä ja toteaa Jorma Koivulehtoon (1999) nojaten ajatuksen "taivaan jumalasta" ja "taivaan isästä" olevan, vanhojen näkemysten vastaisesti, indoeurooppalaista lainaa. Anttosen mukaan jumalaa on käytetty kansanomaisessa miljöössä myös etic-terminä, jota on käytetty noidista ja tietäjistä. Jumalalla on ilmaistu sekä luontoa että luojaa. Ajatus jumalasta on sidottu siis asioihin ja ilmiöihin, joita eivät rajoita fyysisten ja kiinteiden kappaleiden rajat. Yleisemmän jumalia käsittelevän osion jälkeen Anttonen palaa Agricolan jumalluetteloon ja tarkastelee siinä ilmeneviä Karjalan jumalia rinnastaen ne katolilaiseen pyhimyskalenteriin. Käsittelyyn pääsee muun muassa Rauni, tämän suhde Ukkoon ja pihlajapuuhun sekä tätä kautta myös naisen sukuelimiin liittyvä voima ja pyhyys. Pihlajan tarkastelu paljastaa myös hyvin uskomuksiin ja perinteisiin liittyvät ajalliset kerrostumat. Ant- 


\section{Elina Hytönen: Retkiä uskontotieteen kentille}

tonen näyttääkin osuvasti, miten pihlajan pyhyyden taustalla on nähtävissä erilaisia esihistoriallisiin ja kristillisiin perinteisiin juontuvia uskomuksia ja sääntöjä.

Jumalien tarkastelun jälkeen Anttonen ryhtyy käsittelemään peltoa ja siihen liitettyä uskonnollista merkityksenantoa, joka ilmenee esimerkiksi sananparsissa. Tämän merkityksenannon taustalla vaikuttaa maanviljelyn kautta tapahtuva maan arvottaminen elämän lähteenä. Kansanomaisessa ympäristössä uskonto on kytkeytynyt olennaisesti ravintoon ja sen tuotantoon sekä ruoan pyhyyteen. Viimeisessä kappaleessa Anttonen tarkastelee vielä kuolemaa, johon liitettyjä uskomuksia hän pitää yhtenä ihmisyyden yleismaallisena tunnuspiirteenä. Uskontotieteelle kuolema on mielenkiintoista juuri kuoleman sosiaalisen haltuunoton kautta. Kuolemanrituaaleissa on mahdollista tarkastella pyhyyden kahta eri puolta: negatiivista pyhää eli tabua ja positiivista pyhää eli sosiaalista järjestystä.

\section{KAIKKIALLE SEURAAVA USKONTO}

Vaikka kirja pohjaakin Anttosen mittavan uran aikana kirjoittamiin useisiin artikkeleihin, teos onnistuu nivomaan yhteen niin vanhempaa tutkimustietoa kuin uusimpiakin tuulia ilman, että teksti puuroutuu tai lukija kokee tiedon ähkyä. Tällainen uuden ja vanhan keskustelu tuntuu oppikirjaa ajateltaessa erityisen toimivalta ja ajatuksia herättävältä vaihtoehdolta. Selkeydessään teos onkin oivallinen niin perusopintojen tasoisena oppikirjana kuin pidemmälle ehtineen opiskelijan tai tutkijan käsikirjanakin.

Kirjan keskustelut eivät ole antoisia vain uskontotieteilijöille vaan varsin mielenkiintoisia myös muiden tieteenalojen edustajille. Perinteentutkijoiden lähtökohtia palvelee erityisesti Suomea käsittelevä osio, kun taas kulttuurintutkijoille mielenkiintoista aineistoa tarjoaa laajempi kulttuurin ja pyhän käsitteiden tarkastelu. Kirja osoittaa erityisen hyvin sen, miten näiden kolmen tieteenalan, uskontotieteen, perinteentutkimuksen ja kulttuurintutkimuksen, aihealueet ovat ajoittain päällekkäiset. Koska tieteenalojen lähestymiskulmat ovat kuitenkin aina hieman erilaisia, tarjoaa tällainen perusteos läheisten tieteenalojen edustajille varsin virkistäviä näkökulmia tuttuihin aiheisiin. Tämän lisäksi kirja sisältää hyvää keskustelua uskontotieteen ongelmallisuudesta ja suhteesta lähitieteisiin, mikä palvelee myös laajempaa akateemista lukijakuntaa. Kuten Anttonen kirjansa lopussa toteaa, "uskonto seuraa ihmistä kuin varjo" - se on erilaisten perinteiden kautta läsnä yhteiskunnassamme, kulttuurissamme, ruumissamme ja mielessämme. Tähän kaikkialla läsnä olevaan tieteellisesti määriteltyyn uskontoon ja uskonnollisuuteen Anttosen teos tarjoaakin hyvän läpileikkauksen.

\section{KiRjallisuUS}

KOIVULEHTO, JORMA 1999: Varhaiset indoeurooppalaiskontaktit: aika ja paikka lainasanojen valossa. - Fogelberg, Paul (toim.) Pobjan poluilla. Suomalaisten juuret nykeytutkimuksen mukaan. Bidrag till kännedom av Finlands nature och folk 153. Helsinki: Suomen tiedeseura.

TAYLOR, MARK C. 1999: About Religion. Economies of Faith in Virtual Culture. Chicago: 
Elina Hytönen: Retkiä uskontotieteen kentille

The University of Chicago Press.

TURNER, VICTOR \& TURNER, EDITH 1978: Image and Pilgrimage in Christian Culture. New York: Columbia University Press.

Filosofian tohtori Elina Hytönen toimii tutkijatohtorina Itä-Suomen yliopiston filosofisen tiedekunnan humanistisella osastolla. Hän on väitellyt Itä-Suomen yliopiston kulttuurintutkimuksen oppiaineesta vuonna 2010. 